\title{
Moving beyond 'ageing in place': older people's dislikes about their home and neighbourhood environments as a motive for wishing to move
}

\author{
SARAH HILLCOAT-NALLÉTAMBY* and JIM OGGं†
}

\begin{abstract}
Ageing in place has been promoted by policy makers as the optimal residential solution for later life, premised on older people's reluctance to contemplate relocation, their declining residential mobility and high levels of residential satisfaction. This paper takes a critical perspective to the notion of ageing in place by examining older people's dislikes about, rather than levels of satisfaction with their home and neighbourhood environments, and establishing whether such dislikes influence a desire to move. Analysis of the 2004 Living in Wales Survey shows that despite high levels of residential satisfaction, a significant proportion of older people do wish to move. Logistic regression results indicate this desire is strongly associated with dislikes about their immediate home environment, more than neighbourhood factors. Contemplating a move in later life may be shaped more by a desire to 'attach' to people, than to remain in situ to preserve an attachment to place.
\end{abstract}

KEY WORDS - ageing in place, dislikes, residential satisfaction, older people.

\section{Introduction}

In the United Kingdom (UK), policies fostering a philosophy of independent living in later life have reflected the premise that older people are reluctant to move in favour of ageing in place in familiar surroundings (Appleton 2002; Croucher 2008; Sixsmith and Sixsmith 2008), and although over recent years, the residential options available to them have increased through models such as extra-care housing, the majority still live in their own homes (Department for Communities and Local Government

* Centre for Innovative Ageing, College of Human and Health Sciences, Swansea University, UK.

† DSPR, Unité de Recherche sur le Vieillissement, Caisse Nationale d'Assurance Vieillesse, Paris, France. 
2009; Welsh Assembly Government 2008a). From a policy perspective, facilitating ageing in place has therefore meant helping older people to remain in their home (Boaz, Hayden and Bernard 1999; Welsh Assembly Government 2004), with multi-partner community care initiatives playing an instrumental role in facilitating provision of health, personal care and home adaptation services in the community (Audit Commission 1986; Department of Health 2001; McCormick, McDowel and Harris 2009). It has therefore only been very recently that policy makers have begun to consider the possibility that older people may in fact benefit by moving from their home and relocating to alternative living environments (Her Majesty's Government 2011), but very little information or advice has thus far been available to them about options and choices for moving (Burgess 2012).

It is certainly the case that older people's apparent preference for staying put seems to be supported by their patterns of relocation which show that with the exception of persons at advanced ages, home moves decline with increasing age (Angelini and Laferrère 2012; Clark and Huang 2003; Hillcoat-Nallétamby and Ogg 2oog; Sanchez and Andrews 2011 ); compared to younger groups, older people are also less inclined to consider moving (Kearns and Parkes 2003 ) or to actually follow through on such intentions by relocating ( $\mathrm{Lu}$ 1999). There is also a robust body of evidence suggesting that the older we become, the more likely we are to be satisfied with the various dimensions of our residential environment, whether this be the home, the neighbourhood or neighbours (Chapman and Lombard 20o6; Dekker et al. 2011 ; Parkes, Kearns and Atkinson 2002; Perez et al. 2001; Wasserman $1982)$.

Theorists from various fields have offered widely recognised explanations for this apparent desire to stay put and to be satisfied with one's lot in terms of increasing attachment to familiar places and spaces. As older people's feelings for their home and neighbourhood mature with time, as they construct meanings and memorable experiences which they associate with their home (Burholt 2006; O’Bryant and Murray 1986; Scheidt 1993), and as they learn, with varying degrees of success, to align or 'fit' their changing physical and cognitive abilities with the confines and contours of the physical, built dimensions of their home (Carp and Christensen 1986; Kahana et al. 2003; Lawton and Nahemow 1973; Peace et al. 2007), they can become increasingly 'attached' to where they live; all these processes gradually work together to shape a tendency for us to evaluate our residential contexts positively the older we become (Bonaiuto 2004). Hence, older people's sense of attachment to their environment can come from the fact that it provides a familiar landscape which helps maintain, stimulate and support them in preserving a sense of competence in going about their daily activities (Lawton 1988). Equally, across time people may develop an 
emotional attachment to where they live because they have built up memories and meanings about their lives which they do not want to give up. With policy, theory and empirical evidence pointing in apparently similar directions, it therefore becomes difficult to challenge the position that ageing in place in one's own home can be anything else but a desirable outcome for policy makers to support and promote, because older people are seemingly satisfied with this arrangement and do not feel a great desire to move elsewhere.

The aim of this paper is to question this position, and to contribute to critical reflection about the desirability of ageing in place. We propose to do this by developing empirical analysis which focuses on what older people say they dislike, rather than like (or are satisfied with) about their home and neighbourhood environments, and to assess whether these dislikes play a role in shaping a desire to move, even when people are seemingly satisfied with their residential environment. This means that we are proposing a conceptual shift away from assessing older people's subjective appreciations of their residential environments in terms of levels of satisfaction - by far the most common approach taken by researchers, and which hence informs policy - to one which provides an opportunity to see whether, by understanding their dislikes, we can create an alternative platform for recognising and assessing older people's preferences about how and where they live, including options for relocation.

The paper begins with critical reflection on the policy implications of ageing in place and its limitations in facilitating older people's wellbeing. This is followed by a critical review of the more conventional conceptual and methodological approaches used to assess people's subjective evaluations of their home and neighbourhood environments in terms of levels of residential satisfaction, and more specifically, its limitations when used in relation to older people. Using data from the 2004 Living in Wales Survey, we then present results from our empirical analysis which has been designed to examine the likelihood that a desire to move will be shaped by dislikes about home and neighbourhood environments, amongst older Welsh people aged $5^{\circ}$ or more. The paper ends with a discussion of our findings in relation to their policy and theoretical implications.

\section{Critical reflection on ageing in place}

In the UK, the past two decades have seen the organisational framework for social care develop through community care reforms of the 199os, with a progressive shift towards community-based delivery of long-term care services designed to meet personal, nursing and domestic support needs. 


\section{Sarah Hillcoat-Nallétamby and Jim Ogg}

These changes have been driven in large part by the need to find solutions to the increasing costs of these services (Comas-Herrera, Wittenberg and Pickard 2010), and more recently, as part of a drive towards devolving decision-making and implementation mechanisms for service delivery to the local level (Department for Communities and Local Government 2011). The funding of these services has, however, been an on-going issue - in terms of the complexity of funding models which have developed, heavy reliance on informal care to absorb costs, targeting of entitlements through means-testing, and significant geographic variation and inequalities in terms of access, range and quality of services due to highly localised and devolved provisions (Brand, Hughes and Challis 2012). These problems, coupled with increasingly recognised differences across the devolved nations of the UK in terms of welfare rights and entitlements for older people (Chaney 2013), have meant that the costs of long-term care have remained a highly contentious issue, although Scotland's move to make these services free on a universal basis has provided a decisive break with the other three nations. At the time of writing, it is only in 2013 that the current UK Coalition Government has taken a clear step for England in introducing a cap to the total amount that people will be expected to contribute towards the costs of the nursing or personal care components (but not the 'hotel' costs of accommodation and food) of their long-term care.

These local, community-based service agendas have run in parallel to another, which has emphasised the importance of enhancing older people's choices and options for personalised services as consumers in a market context of social care delivery (Comas-Herrera, Wittenberg and Pickard 2010; Means 2011). However, this agenda has also resulted in variations in terms of political commitment, implementation and funding across the devolved nations, notably with regard to health (Peckham et al. 2012). Such difficulties notwithstanding, ageing in place has nonetheless been the cornerstone for the implementation of these different policy agendas, with the home environment becoming the nexus for the delivery of personal and health-care services and as a space which can be adapted to fit the changing requirements of later life.

There is, however, evidence to suggest that this focus on the home has been at the expense of considering the dwelling as integral to its socio-spatial location within neighbourhood and community contexts, both of which are important in influencing older people's sense of satisfaction, happiness and quality of life (Baressi, Ferraro and Hobet 1984; Kozma and Stones 1983). Research has not only demonstrated how the inter-connectedness of different dimensions of the residential environment in terms of people, place and space influences wellbeing (Adriaanse 2007; Canter and Rees 1982; Francescato 2002), but for older people in particular, has shown how a 
wide range of factors, including the aesthetic, design and health features of the environment, accessibility of local services and amenities, perceptions of neighbourhood safety, and neighbourhood relationships, are important components in shaping their perceptions of residential satisfaction (Carp and Carp 1982; Golant 1984; Kahana et al. 2003; Lawton 1988; Rioux and Werner 2011).

Such evidence points to the need for more holistic and integrated approaches to designing environments which are well suited to ageing in place (Greenfield 2012; Oswald et al. 2010), but this has only very recently begun to emerge in the policy sphere through, for example, concepts such as the lifetime home located in a lifetime neighbourhood (Department of Communities and Local Government 2008). Furthermore, whilst attempts to establish best practice design recommendations for housing in the UK and to increase the breadth of housing options for older people are beginning to appear (Her Majesty's Government 2011; Homes and Communities Agency, Department of Health, and Communities and Local Government 2009; Porteus 2011; also Building for Life ${ }^{1}$ ), these initiatives, from both public and private sectors, still confront significant barriers, notably in terms of planning and funding restrictions (Monk and Burgess 2012). Other policy challenges relating to ageing in place include the uncertainty of funding, grant or benefit streams to support adaptations or works to the home such as the home handyperson services. Similarly, in terms of facilitating choices about whether to age in place, local authority efforts in England and Wales have only recently focused on improving the supply of information about housing options for older people (Burgess 2012; Welsh Assembly Government 2008b), or of promoting localised residential mobility opportunities in the social housing sector through 'house swapping' initiatives (http://www.nwha.org.uk). ${ }^{2}$

Older people's own preference for staying put in their homes has provided a compelling rationale for continuing to encourage ageing in place, but has also meant that much less attention is paid to the significant evidence base suggesting that it may not be the best option for enhancing wellbeing (Golant 2008; Means 2007; Oldman and Quilgars 1999; Oswald and Rowles 2006), when for example, difficulties with home maintenance occur (Fausset et al. 2011), as health and functional abilities decrease (Rubenstein, Kilbride and Nagy 1992), when homeownership costs increase (Askham et al. 1999) and when family composition changes (Sabia 2008). Research has also pointed to the tendency for the home context to be overromanticised as the ideal living environment for fostering independence (Oldman and Quilgars 1999), and to ignore its potential as a place which can create feelings of social isolation (Barrett, Hale and Gauld 2012; Milligan 2009; Plath 2008; Sixsmith and Sixsmith 2008), alienation and 


\section{Sarah Hillcoat-Nallétamby and Jim Ogg}

disempowerment (Rabiee 2012), particularly if it becomes the site for intensive medical treatment and service intervention (Baldwin, Harris and Kelly 1993; Percival 2002). Housing adaptations are seen as a key means of facilitating ageing in place (Heywood and Turner 2007), and whilst some research indicates their beneficial effect in helping to maintain daily activities and independent living (Harper and Bayer 2000; Hwang et al. 2011), other studies have been unable to confirm either this (Gitlin 1998) or the impact of adaptations in reducing the risks for older people of incurring injuries at home (Lyons et al. 2006).

The desirability of ageing in place is often contrasted with the stress of relocation in later life (Oswald and Rowles 20o6), but whether the outcomes of moving prove beneficial may vary depending upon how well the new environment 'fits' with the older person's needs and initial motives for moving (Peace, Holland and Kellaher 2006) or how well individuals have integrated changes to their environment across their lifecourse rather than at one particular point in time (Rowles and Watkins 2003). Little attention has been paid to evidence that older people in fact anticipate moving when opportunities for receiving good care are rated more highly than staying put (Seppänen 2012) and when they become aware of alternative options such as relocation (Peace, Holland and Kellaher 2011), or to research which demonstrates the positive accounts given by some older people when they have relocated to a collective or institutional setting (Boyle 2004; Martin et al. 2005). Finally, the focus of most research on the outcomes of relocation in later life has been on the transition to institutional settings (Castle 2001), and the limited evidence available about other types of relocation transitions shows that older people report a more nuanced and complex picture than a simple dualistic reaction of either optimal/positive and detrimental/ negative outcomes (Sima et al. 2012). Stimson and McCrea's (2004) study of transitions to a retirement village, for example, found that overall residential satisfaction was high amongst those who had moved, and although not conclusive, there is some evidence to suggest that when older people have moved, they are more likely to be satisfied with the state of repair of their new home, suggesting that relocation can bring with it improvements in terms of the immediate living environment (Hillcoat-Nallétamby and Ogg 2009).

\section{Critical review of residential satisfaction}

The emphasis on facilitating ageing in place at home because older people show such high levels of satisfaction with familiar surroundings has arguably side-stepped both methodological and theoretical explanations of why such 
positive appraisals may characterise their subjective assessments of home and neighbourhood. Amérigo and Aragonés (1997) argue that the concept of residential satisfaction poses interpretive challenges because of its relative plasticity in circumstances when individuals can do little to change their situation, and so accommodate their lack of satisfaction by progressively altering expectations about what constitutes an acceptable quality of living conditions.

Zapf $(1984,2000)$ and Noll's four-category typology of welfare positions (Noll 1980; Noll and Zapf 1994) which combines information about objective living conditions and individuals' subjective appreciations of wellbeing, identify an 'adaptation' group, people who simultaneously report experiencing objectively measured poor living conditions along with high levels of subjective satisfaction. The problem raised by this category is what Noll and Zapf (1994) refer to as the 'satisfaction paradox'; these individuals potentially represent groups who are powerless to change their circumstances and therefore adapt subjectively to their situation, thus rendering them invisible in the policy process. Adapting their typology to the European context, Delhey (2004) found that a quarter of individuals across 13 countries fell into the category of 'adaptation', that is they were satisfied with their neighbourhood despite harbouring complaints about it. For older people in particular, these theoretical explanations may well elucidate some of the reasons why they report such high levels of residential satisfaction, fearing, for example, that any indication of dissatisfaction or inability to cope in current living circumstances may raise the prospect of relocation to an institutional context. As Delhey (2004) suggests, another reason for this 'satisfaction paradox' and which may well apply to older people, is that people's positive assessments of such intimate domains as home and neighbourhood reflect a sense of control over these 'private' areas of life. Perez et al. (2001) found, for instance, that residential satisfaction amongst older Spanish people ageing in place was higher, the greater the control they could exercise over decisions affecting the home.

Other explanations about high levels of residential satisfaction point to more generic conceptual and methodological shortcomings: the propensity for people to want to use positive rather than negative language when questioned (Francescato, Weidemann and Anderson 1987); the difficulties in establishing the actual meaning attributed to 'satisfaction' and whether it is interpreted as a general state or in relation to specific dimensions of the residential environment (Amérigo and Aragonés 1997; Miller et al. 1980); whether the parameters of residential environments should be based on objective, cartographic criteria or on the subjective perceptions and meanings held by residents themselves (Amérigo and Aragonés 1997; Francescato 2002); and whether the validity of objective measures such as 


\section{Sarah Hillcoat-Nallétamby and Jim Ogg}

housing quality, are really just social constructs which reflect the technical criteria of housing experts (Francescato 1987; Harrison 2004). Finally, although few studies focus on residential dissatisfaction, those that do have not tended to offer significantly new approaches to its conceptualisation or measurement, but rather, have assessed it on a continuum of satisfaction scales (Healy 2003; Mohan and Twigg 2007; Kearns and Parkes 2003; Parkes, Kearns and Atkinson 2002).

From our critical review of the literature on the limitations of ageing in place from both policy agenda and personal choice and wellbeing perspectives, combined with the theoretical insights and methodological challenges involved in continuing to assess residential satisfaction, there is a need to explore alternative approaches to gauging how older people subjectively evaluate their home and neighbourhood environments, and to then establish whether, by shifting focus to another conceptual tool, we can shed further light on older people's perceptions about the desirability of ageing in place.

\section{Empirical analysis}

Moving on from a focus on residential satisfaction, our empirical analysis of older people's dislikes about their home and neighbourhood and their desire to move, is based on data from the 2004 Living in Wales Survey which provides the only national-level source of information on households and housing conditions. The survey involved interviews with a total of 7,526 households, one person per household providing information on all household members, giving a total of 18,145 people. The questionnaire contains a module on respondents' subjective perceptions of satisfaction, as well as their likes and dislikes about home and neighbourhood environments, and information on respondent and household member characteristics, recent housing history, and objective features of the home environment. Our analysis is based on respondents aged $5^{\mathrm{O}}$ or more $(\mathrm{N}=4,079)$.

\section{Data, methods of analysis and variable specification}

\section{Moving desires}

Data for the dependent variable about wishes to move come from the survey question on whether respondents expressed a desire to move from their current property: 'Would you currently like, or do you need, to move out of this property into somewhere else?' The question had four response 
categories: 'yes, like to'; 'yes, need to'; 'no'; 'don't know'. In our study population, 15.4 per cent said they would like to move, and another 3 per cent said they felt a need to move, the remainder not wishing to move (including less than 2 per cent who did not know what they wanted to do). For the purposes of statistical analysis, the categories of 'yes, like to' and 'yes, need to' were merged, and the dependent variable created by recoding responses into a dichotomous response: 'yes wants to move/no does not want to move'. We have used binary logistic regression to establish which factors, including dislikes, are the most likely to influence the probability of respondents expressing a desire to move. The model coefficients are expressed as odds ratios ( $\mathrm{OR} ; 1=$ wants to move; $\mathrm{O}=$ does not want to move).

\section{Subjective residential perceptions: satisfaction and dislikes}

The 2004 Living in Wales Survey provides two distinct sets of survey questions relating to satisfaction, on the one hand, and likes and dislikes, on the other. Three general questions ask how satisfied or dissatisfied respondents were overall with their home, its state of repair and neighbourhood as a place to live ('Overall, how satisfied or dissatisfied are you with your home?'), with responses recorded on a six-point Likert scale ranging from 'very satisfied' to 'very dissatisfied' and 'no opinion'. The survey conceptualised residential dislike in terms of older people's subjective, experiential appreciations of both the internal and external aspects of their dwelling, and characteristics of their neighbourhood. Two questions with multiple responses asked respondents what they liked and disliked about their home, and then their neighbourhood, in terms of the internal and external aspects for the home, and then people and facilities for the neighbourhood. Where the interviewer could not code responses, an open text code was recorded and a code 'other' was ascribed. We analysed the qualitative answers for the 'other' category for meaning in terms of whether they related to factors relating to the home or neighbourhood environment, and regrouped and recoded them accordingly. For the logistic regression analysis, we created a summary independent variable as follows: 'no dislikes' (respondents who had no dislikes about home or neighbourhood); 'home only' (at least one dislike about home only); 'neighbourhood only' (at least one dislike about neighbourhood only); 'home and neighbourhood' (at least one dislike about home and neighbourhood). Each category of the variable is therefore mutually exclusive.

The logistic regression modelling also includes other independent variables which capture individual and household characteristics (gender, age, self-reported health status, household type, tenure, place of birth, Welsh speaking), objective features of the dwelling (period of construction, type of 


\section{Sarah Hillcoat-Nallétamby and Jim Ogg}

dwelling, shower, kitchen and central heating amenities) and respondents' subjective evaluations of heating and home security effectiveness. We also consider whether a desire to move will be influenced by older people's 'attachment to place', captured through variables on length of time at the current address, interaction with neighbours and engagement in local organisational activities. We therefore take all three measures of 'attachment to place' as representing attachments stemming from the symbolic meanings and cumulative experiences which older people have developed over time and which affect their emotional attachment to their current location, rather than in terms of its functional role in enhancing feelings of competence. Tests for multicollinearity confirmed that the independent variables were not significantly related (variance inflation factors $<5$ ).

\section{Results}

In the following section, we first present findings on older people's subjective reports of how satisfied they are with their home and neighbourhood environments, and then focus on their dislikes and a desire to move, using both descriptive and logistic regression results.

\section{Being satisfied but still harbouring dislikes about home and neighbourhood}

When asked how satisfied they are with their home and neighbourhood contexts, the vast majority of older people in Wales aged $5^{\circ}$ or more report very high levels of satisfaction with both domains. Table 1 shows that over go per cent say they are either very or fairly satisfied with their home $(72.3$ and $22.7 \%$, respectively), and its state of repair (56.9 and $32.7 \%$, respectively), as well as with their neighbourhood (64.9 and $26.3 \%$, respectively). However, about one-fifth also say they would like to $(15.4 \%)$ or need to $(3.0 \%)$ move from their current home. Clearly then, feeling highly satisfied with one's residential environment does not preclude older people from harbouring a desire to relocate.

Equally, we find that being highly satisfied does not preclude older people from harbouring dislikes about their living environments, as more than six out of ten $(61.7 \%)$ say they dislike at least one feature of their home, neighbourhood or both (Table 1 ). Each category of this variable is mutually exclusive, 17 per cent disliking at least one thing about their home only, 21 per cent something about their neighbourhood only and a further quarter $(23.7 \%)$ disliking at least one thing about both. In terms of wishing to move from their current home, 15.8 per cent say there is nothing they dislike about their home or neighbourhood, so clearly other 'push' or 'pull' factors 
T A B L E 1. Socio-demographic and household characteristics, population $5^{O}+$, by desire to move from current home

\begin{tabular}{|c|c|c|c|}
\hline Variables & Yes, like or need to move & No & Total \\
\hline \multirow[t]{2}{*}{$\mathrm{N}(\%)$} & $75^{1}(18.4)$ & $3,328(81.6)$ & $4,079(100)$ \\
\hline & \multicolumn{3}{|c|}{ Percentages } \\
\hline Satisfied with home & $87 \cdot 7$ & 96.6 & $95 \cdot 0$ \\
\hline Satisfied with state of repair & 81.4 & 91.4 & 92.4 \\
\hline Satisfied with neighbourhood & 74.2 & 74.8 & 91.1 \\
\hline \multicolumn{4}{|l|}{ Dislikes: } \\
\hline None & 15.8 & $43 \cdot 4$ & 38.3 \\
\hline Home only & 21.4 & 16.2 & 17.2 \\
\hline Neighbourhood only & 18.8 & 21.2 & 20.8 \\
\hline Both & $43 \cdot 9$ & 19.1 & $23 \cdot 7$ \\
\hline \multicolumn{4}{|l|}{ Gender: } \\
\hline Women & $5^{6.5}$ & $55 \cdot 2$ & $55 \cdot 4$ \\
\hline Men & $43 \cdot 5$ & 44.8 & $44 \cdot 6$ \\
\hline \multicolumn{4}{|l|}{ Age: } \\
\hline $5^{\mathrm{O}-59}$ & $4^{0} \cdot 3$ & 32.4 & 33.8 \\
\hline $6 o-69$ & 34.0 & 28.5 & $29 \cdot 5$ \\
\hline $70-79$ & 18.4 & 25.1 & 23.9 \\
\hline $80+$ & $7 \cdot 3$ & 14.1 & 12.8 \\
\hline Long-term ill or disabled & 42.1 & $35 \cdot 7$ & 36.8 \\
\hline Born in Wales & 66.8 & 69.2 & 68.8 \\
\hline Welsh-speaking household & 21.3 & $24 \cdot 7$ & 24.1 \\
\hline \multicolumn{4}{|l|}{ Tenure: } \\
\hline Owns & 73.2 & $79 \cdot 0$ & $77 \cdot 9$ \\
\hline Rents & 26.8 & 21.0 & 22.1 \\
\hline \multicolumn{4}{|l|}{ Type of household: } \\
\hline One person & 36.0 & 37.6 & 36.0 \\
\hline Couple only & 40.5 & 43.8 & 40.5 \\
\hline Other & 23.6 & 18.6 & 23.6 \\
\hline \multicolumn{4}{|l|}{ Time at current address: } \\
\hline $0-2$ years & 10.4 & 8.8 & 9.1 \\
\hline $3^{-10}$ years & 20.6 & 21.7 & 21.5 \\
\hline $11-20$ years & 22.1 & 18.4 & 19.1 \\
\hline $21+$ years & $4^{6.9}$ & $5^{1.0}$ & $5^{0.3}$ \\
\hline Central heating & 92.4 & 92.8 & 92.7 \\
\hline Separate kitchen & 90.0 & 90.0 & 90.0 \\
\hline Sole/shared use of shower & 71.6 & $75 \cdot 5$ & 74.8 \\
\hline \multicolumn{4}{|l|}{ Home period of construction: } \\
\hline$<1919$ & $27 \cdot 7$ & 27.0 & 27.1 \\
\hline $1919-1944$ & 12.4 & $13 \cdot 3$ & 13.1 \\
\hline $1945^{-1964}$ & 20.8 & 22.6 & 22.3 \\
\hline$>1964$ & $39 \cdot 1$ & $37 \cdot 1$ & $37 \cdot 5$ \\
\hline \multicolumn{4}{|l|}{ Dwelling type: } \\
\hline House & 76.6 & 71.6 & 72.5 \\
\hline Flat & 11.3 & 8.7 & 9.1 \\
\hline Bungalow & 12.1 & $19 \cdot 7$ & 18.3 \\
\hline \multicolumn{4}{|l|}{ Home security effectiveness: } \\
\hline Very effective & 37.0 & $44 \cdot 3$ & $43 \cdot 0$ \\
\hline$<$ Very effective & 63.0 & $55 \cdot 7$ & $57 \cdot 0$ \\
\hline
\end{tabular}


1782 Sarah Hillcoat-Nallétamby and Jim Ogg

TA B LE 1. (Cont.)

\begin{tabular}{lccc}
\hline Variables & Yes, like or need to move & No & Total \\
\hline Effectiveness of heating: & & & \\
$\quad$ Very effective & 66.7 & 76.1 & 74.3 \\
$\quad<$ Very effective & $33 \cdot 3$ & 23.9 & $25 \cdot 7$ \\
Regular participation in activities & $43 \cdot 9$ & 48.2 & $47 \cdot 4$ \\
Talk to neighbours most days & $53 \cdot 3$ & 63.9 & 61.9 \\
\hline
\end{tabular}

are at play. For the remainder of older people who do wish to move, the majority dislike something about both their home and neighbourhood contexts $(44 \%)$, a rate that is more than double compared to those respondents not wanting to move.

\section{Types of dislikes}

Focusing our analysis now on older people who had at least one dislike, and bearing in mind that the question involved multiple responses for each domain, on average, respondents reported 1.3 dislikes about their home (with base as 'has a dislike about the home') and 1.5 about their neighbourhood (with base as 'has a dislike about the neighbourhood'). At the descriptive level at least, Table 2 suggests that with regard to their immediate neighbourhood vicinity (Total column), respondents were most likely to dislike the presence of young people 'hanging around' (12.3\%), as well as people and neighbours in general $(8.1 \%)$, a poorly maintained and noisy local environment ( 9.9 and $8 \%$, respectively), and one which they perceive lacks adequate services, infrastructures or amenities such as car parking, public transport and shops $(7.2,7 \cdot 3$ and $7 \cdot 4 \%$, respectively).

However, reading across Table 2 from column 1 to 4 , the older people become, the less concerned they appear about the presence of younger people or the lack of facilities for this age group, the less troubled they are by noise in their vicinity, and surprisingly, seemingly less concerned about public safety and security. Conversely, with increasing age, people dislike their neighbourhood more if it does not provide them with a good shopping infrastructure, and although not reported very often, if it does not leave them with a sense of community belonging and inclusion.

Turning now to the home, what respondents seem to dislike most about their current dwelling are things to do with its physical aspects: its design features $(7.7 \%)$, size $(6.9 \%)$, location $(8.9 \%)$ and that it has a garden $(7.1 \%)$. With increasing age, dislikes about the size of rooms, bathroom and kitchen facilities seem to become less important, but concerns about the property in terms of external maintenance increase. In sum, these 
T A B L 2. Dislikes about home and neighbourhood by age and total dislikes - multiple responses
(1) $5^{\mathrm{O}-59}$
(2) $60-69$
(3) $7 \mathrm{O}^{-}-79$
(4) $80+$ Total

Home:

\begin{tabular}{|c|c|c|c|c|c|}
\hline Layout/design/type of property & 13.0 & $9 \cdot 4$ & $7 \cdot 9$ & 12.8 & $7 \cdot 7$ \\
\hline Size of rooms & 11.7 & 8.8 & 8.2 & $7 \cdot 4$ & 6.9 \\
\hline Location/position/view & 11.4 & 13.6 & 13.0 & 12.2 & 8.9 \\
\hline Has garden & 10.6 & 9.0 & $9 \cdot 7$ & 10.1 & 7.1 \\
\hline Bathroom & 8.4 & $7 \cdot 9$ & $7 \cdot 3$ & 6.8 & 5.6 \\
\hline $\begin{array}{l}\text { Internal condition } \\
\text { (modernisation/repairs, etc.) }\end{array}$ & 8.4 & 6.7 & 8.5 & 6.8 & $5 \cdot 5$ \\
\hline Kitchen & 7.8 & $9 \cdot 4$ & 8.8 & $5 \cdot 4$ & $5 \cdot 9$ \\
\hline Number of rooms & 7.0 & 6.1 & $5 \cdot 2$ & $7 \cdot 4$ & $4 \cdot 6$ \\
\hline $\begin{array}{l}\text { External condition/ } \\
\text { maintenance }\end{array}$ & 6.9 & 6.9 & 8.8 & 10.1 & $5 \cdot 4$ \\
\hline People/neighbours & 6.1 & $5 \cdot 9$ & 10.0 & $7 \cdot 4$ & $5 \cdot 0$ \\
\hline Condition of windows & $5 \cdot 5$ & $5 \cdot 2$ & $5 \cdot 5$ & 6.8 & $3 \cdot 9$ \\
\hline Damp/condensation & $4 \cdot 5$ & $4 \cdot 2$ & $4 \cdot 5$ & $3 \cdot 4$ & 3.1 \\
\hline Noise/lack of soundproofing & $4 \cdot 3$ & 2.5 & 3.6 & 2.0 & 2.4 \\
\hline Heating/hot water & 4.0 & 4.8 & 6.4 & $3 \cdot 4$ & $3 \cdot 3$ \\
\hline Amount of storage space & 2.8 & 1.3 & 4.2 & $3 \cdot 4$ & 2.0 \\
\hline Not having a garden & 1.9 & 1.9 & 0.9 & 2.7 & 1.3 \\
\hline Lack of privacy & 1.5 & 1.5 & 1.5 & 1.4 & 1.1 \\
\hline $\begin{array}{l}\text { Inconvenient for local } \\
\text { amenities/transport }\end{array}$ & 0.9 & 0.8 & 1.5 & 0.0 & 2.0 \\
\hline $\begin{array}{l}\text { Internal security } \\
\text { (locks, chains, entry phones) }\end{array}$ & 0.7 & 0.2 & 0.9 & 1.4 & 0.5 \\
\hline Quiet & 0.6 & 0.8 & 0.3 & 2.0 & 0.5 \\
\hline Base number & 668 & $55^{2}$ & $33^{\circ}$ & $14^{8}$ & $2,33^{6}$ \\
\hline \multicolumn{6}{|l|}{ eighbourhood: } \\
\hline $\begin{array}{l}\text { Children/young people } \\
\text { hanging around }\end{array}$ & $19 \cdot 4$ & 20.0 & 18.7 & 14.5 & 12.3 \\
\hline Noisy/not peaceful & 15.1 & 10.2 & 11.4 & 9.9 & 8.0 \\
\hline Not well-maintained/dirty/litter & 14.6 & 16.2 & 16.4 & 11.8 & $9 \cdot 9$ \\
\hline Car parking & 12.4 & 10.2 & 10.4 & 10.5 & 7.2 \\
\hline People/neighbours & 11.7 & 13.6 & 12.4 & 13.2 & 8.1 \\
\hline Poor public transport & 11.4 & 10.2 & 12.4 & 11.8 & $7 \cdot 3$ \\
\hline No/poor facilities for teenagers & 11.3 & 8.2 & $3 \cdot 7$ & $3 \cdot 3$ & $5 \cdot 2$ \\
\hline No/poor shops & 10.7 & 11.3 & 11.7 & $14 \cdot 5$ & $7 \cdot 4$ \\
\hline Not safe/secure/lot of crime & $9 \cdot 3$ & 9.8 & 8.2 & 6.6 & 5.8 \\
\hline Drug users/pushers & 8.6 & $7 \cdot 3$ & 4.0 & 2.0 & $4 \cdot 3$ \\
\hline No/poor facilities for children & 8.2 & 7.6 & 2.5 & 3.9 & 4.1 \\
\hline No sense of community & 2.8 & $4 \cdot 2$ & $5 \cdot 5$ & 8.6 & 2.8 \\
\hline Isolated & 1.7 & $3 \cdot 3$ & 4.0 & $3 \cdot 9$ & 1.9 \\
\hline Poor schools & 1.1 & 0.0 & 0.2 & 0.0 & 0.3 \\
\hline Base number & 710 & $55^{\circ}$ & 402 & $15^{2}$ & $2,33^{6}$ \\
\hline
\end{tabular}

descriptive findings initially suggest that overall, in terms of thinking about ageing in place and things that older people dislike about their neighbourhood, dislikes about people, place and amenities all count. When we take age 


\section{Sarah Hillcoat-Nallétamby and Jim Ogg}

into account, however, the older people become, the less bothered they are about nuisance in their vicinity to do with youth, crime and general lack of tranquillity, and potentially more so with perceptions of being socially marginalised from their local community. Being able to access local shops is clearly something which becomes more important with age. When it comes to their home, whilst the dislikes they have about maintaining their properties could eventually be addressed, those pertaining to the actual design, location or layout of their homes suggests that moving would be the only option.

\section{Moving desires}

Having examined the nature of older people's dislikes and whether there is evidence to suggest that these vary by age, we now examine whether they play a role in shaping a wish to move, even when we know that the majority of the study population have said that they are very or fairly satisfied with either their current home, its state of repair or their neighbourhood.

In our study population (Table 1), 55 per cent are women, about 37 per cent aged over 70 ( $13 \%$ amongst the very old), with over one-third declaring a long-term illness or disability. The majority are Welsh born, but only a quarter speak the language at home, most are home owners and about two-thirds live with a partner or someone else. Half have not moved from their current home within the last 21 years or more, although about a third have relocated. Although about two-thirds talk to their neighbours on most days, only about half are involved regularly in organisational activities. In terms of their home environment, about 40 per cent live in properties of the pre-War period, the majority of which are houses. About 6o per cent are not happy with the effectiveness of their home's security features, and a quarter with the effectiveness of their home heating. Although almost all have central heating and a separate kitchen, a quarter do not have a shower. The likelihood of wanting to move seems to reduce with age (Table 1), but contemplating a move may be more likely for older people with a long-term illness, who rent their accommodation, live in a house or flat, and think their heating and home security are not very effective. Being less engaged in social activities seems to increase older people's likelihood of contemplating a move.

\section{Logistic regression results}

Our regression analysis confirms the factors which are associated with the likelihood that older people would like to, or feel they need to move as 
T А В L E 3. Logistic regression results: odds ratios for wanting to move versus not wanting to move

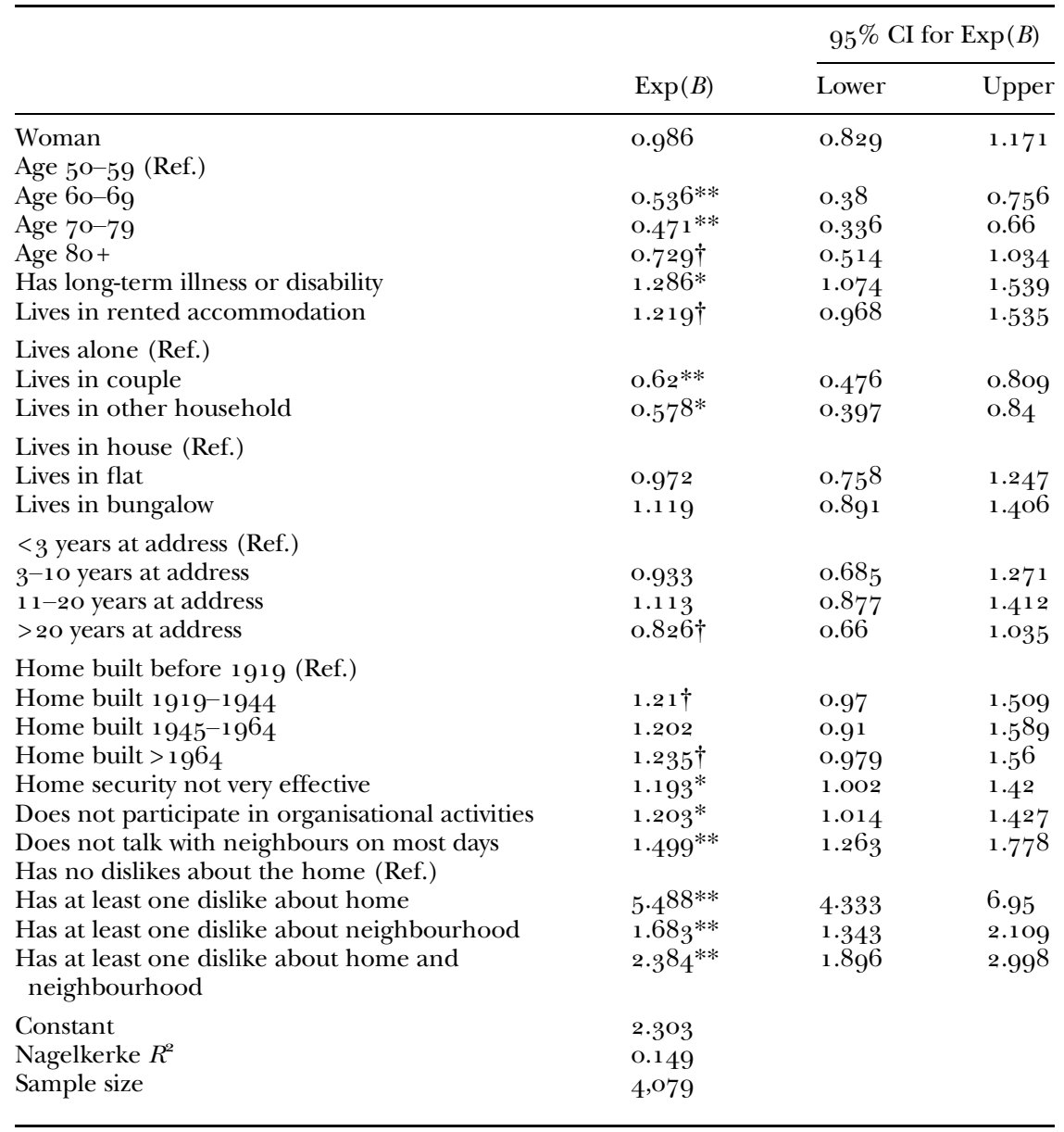

Notes: CI: confidence interval. Ref.: reference category.

Significance levels: $\dagger p<0.1, * p<0.05$, $* * p<0.01$.

opposed to staying put and ageing in place in their current dwelling. Table 3 presents the results for the most parsimonious model.

First, in response to our aim of establishing whether older people's dislikes of their home or neighbourhood can shape a desire to move, even when they report high levels of satisfaction with one or both of these, we certainly find that this variable is significantly associated with such desires; indeed it shows the strongest coefficients in the model. Having a dislike, whether this is about the home, the neighbourhood or both, clearly increases the 


\section{Sarah Hillcoat-Nallétamby and Jim Ogg}

likelihood that older people will contemplate a move. Those who say they dislike at least one thing about their home are five and a half times more likely to be contemplating a move than people who have no dislikes (OR $5.48, p<0.01)$ and those disliking something about their neighbourhood close to two times more likely (OR $1.68, p<0.01$ ), with the group harbouring dislikes about both aspects of their residential environment, almost two and a half times more likely ( $\mathrm{OR} 2.38, p<0.01)$. The first result suggests that it is the home, more than the neighbourhood environment, which prompts a wish to move - in other words, older people may be happy with their neighbourhood but not their immediate living environment. Other research completed using the same data set which compared older movers with stay putters effectively corroborates this interpretation, as those who had moved were more likely to consider their home to be in a good state of repair (Hillcoat-Nallétamby and Ogg 2009). Although not focusing specifically on older people, research in the English context has shown that dissatisfaction with the home has a more marked influence on moving than dissatisfaction with neighbourhood and surrounding features (Kearns and Parkes 2003).

In terms of the other individual or household factors which are significantly associated with the likelihood of older people expressing a wish to move, age, perceived health status, household type and, to a lesser extent, tenure are significant. Until they are in their eighties, people are about $5^{\circ}$ per cent less likely to want to move than those in their fifties (OR $0.53, p<0.01$ and $0.47, p<0.01)$, although once they reach very old age, people may begin to contemplate relocation ( $\left.\mathrm{OR} 0.7^{2}, p<0.1\right)$. This latter interpretation corresponds to wider European patterns of actual residential mobility in later life which are more pronounced for those aged 80 or more (Angelini and Laferrère 2012). Having a long-term illness or disability also shapes a wish to move for older people living with these difficulties (OR 1.28, $p<0.05$ ), and will also depend upon whether they are living with others; those sharing their home with a partner or someone else, for example, are about 40 per cent less likely to be contemplating relocation compared to those living by themselves (OR $0.62, p<0.01$ and $0.57 p<0.05$ ). Although statistically weak, the OR values for tenure suggest that older people renting their accommodation are more likely to be thinking about a move compared to those who own their own home (OR 1.21, $p<0.1)$.

The date of construction of their homes does not seem to have a really significant effect on whether older people are thinking about a move, although if they perceive the security measures in their home to be ineffective, these probably will (OR $1.19, p<0.05)$. Surprisingly, the length of time older people have lived at their current address seems to have no really significant effect on whether they wish to move, but reduced contact 
with people in their local area, because they do not talk regularly to neighbours (OR 1.49, $p<0.1$ ) or do not participate in local activities (OR 1.2, $p<0.05$ ), will shape these intentions.

\section{Discussion}

The aim of this paper is to bring critical reflection to the position that facilitating ageing in place at home is a desirable policy objective because it corresponds both to what older people say they want and are satisfied with, and to their decreasing propensity to move in later life. We have addressed this aim against a background of literature which provides a critical lens to the relationship between older people and their residential environments, and pinpointing the challenges of ageing in place in a policy climate of deinstitutionalised, community-based, personal and health-care provisions. From an empirical perspective, we have introduced a conceptual shift away from assessing older people's subjective perceptions of how satisfied they are with their residential environment to assessing what they actually dislike about it, and seeing whether such dislikes play a role in shaping a desire to move, even when most older people in Wales are seemingly satisfied with their immediate home and neighbourhood contexts. Our findings have demonstrated the potential relevance of making this conceptual shift.

From a methodological perspective, our findings provide a sound rationale for others to develop a more rigorous use of the concept and terminology of 'dislikes' as distinct from 'dissatisfaction' which has traditionally been measured as part of a continuum of 'satisfaction', if our aim is to improve understanding about older people's experiences of ageing in place, and their decision-making process about moving. Equally, if we see ageing in place as part of a continuum of life-long experiences, punctuated by events which may shape older people's housing trajectories at various points in their lives, the concept of 'dislikes' could well provide a new 'marker' for monitoring these internal decision-making processes (Amérigo and Aragonés 1997).

In terms of the paper's focus on developing more of a critical reflection on the policy drive for ageing in place, our findings have made several contributions. First, although the desire to move clearly reduces with age, we find that those with a long-term illness or disability will be more likely to contemplate relocation. As people advance into very old age, these limitations will often become more constraining, and so a different set of motivations about the desirability of ageing in place may well come into play, particularly if such impairments become increasingly important in an older person's ability (or perception) to remain mobile and autonomous at home. 


\section{Sarah Hillcoat-Nallétamby and Jim Ogg}

Our findings that the odds of wanting to move are higher for those with a long-term illness or disability suggest that the 'fit' or 'liveability' of the home environment is not congruent with changing physical need; in other words, that 'ageing in place' is not a continuous, uniform experience or solution, but will vary in its 'do-ability' depending upon evolving lifecourse needs.

Second, as our regression analysis has shown, wishing to move is more pronounced for dislikes about the home than the neighbourhood, and along with our descriptive analysis of the actual nature of dislikes, indicates that older people's concerns about the structural design features, location and maintenance aspects of their home environment can lead to serious consideration of residential mobility. This suggests that the design constraints of the home environment can potentially impede a sense of personal competence about being able to age in place, to the extent that feelings of attachment to place are progressively overridden, giving way to thoughts about the desirability of moving. These findings point to the need for critical reflection in policy about the importance of preserving familiarity with place and people through ageing in place, if, in reality, older people find it increasingly difficult to address the more practical constraints imposed by the home environment; in other words, listening to dislikes about the home environment could be a window for intervention which facilitates moving rather than an opportunity for making physical and psychological adaptations to an existing environment.

Third, whilst our findings show that older people are certainly more likely to harbour dislikes about their home compared to their neighbourhood (at least in terms of odds ratios), our descriptive analysis nonetheless suggests that preferences and priorities change as we age, having access to local facilities such as shops or transport for example, take on increasing importance the older we become (De Jong, Rouwendal and Brouwer 2012). Facilitating ageing in place therefore needs to be premised upon a strategic approach which recognises the interconnectedness of home and the place in which it is located.

Finally, we have found that the strength of relations with neighbours and other community members contribute to decision-making processes about relocation (although not necessarily their outcomes). Taking this further, if we interpret, on the one hand, a lack of regular interaction with neighbours and engagement in local activities as a sign of reduced 'attachment' or 'belonging to' the neighbourhood context, with on the other, a propensity to contemplate relocation if living alone or when there is a concern over the security of the home, then our results suggest a broader motivation for wishing to move linked to anxieties about vulnerability or solitude which can accompany ageing in place in later life. In short, a potential fear of vulnerability in living alone, coupled with a lack of engagement in 
communities of people, suggest that contemplating a move may be shaped more by a desire to 'attach' to people, than to remain in situ through preference for preserving any 'attachment to place'.

We do recognise that our study has some limitations which stem primarily from the nature of the Living in Wales Survey data. There is limited information on respondents' socio-economic profiles: $e$.g. questions about educational qualifications or years of schooling are only asked of respondents who speak Welsh, a significant proportion $(41 \%)$ did not provide any information about their household income, and there is no question on individual income. Second, and more central to the paper's scientific objective, the research does not take account of the whole range of 'push' and 'pull' factors which have been established as influencing relocation decision-making processes and behaviour (Weeks, Keefe and Macdonald 2012), notably because the survey included filters which meant that some questions were asked only of those who had moved. The variables on 'attachment to place' do represent proxies for 'pull' factors concerning the desire to remain in the current location, but the data set does not enable us to include some of the 'pull' factors which might draw people into a desire to move, such as wanting to be close to family, a factor which previous research has shown to be a significant reason in explaining older people's recent relocation behaviour in Wales (Hillcoat-Nallétamby and Ogg 2009). What the model captures most effectively through the 'dislikes' variables therefore, are the 'push' factors - things that people feel would make them move.

Finally, in the absence of robust, longitudinal data for the Welsh context, our focus has been on examining the relationship between dislikes and one stage of the residential mobility decision-making process - the desire to move - rather than the complementary stages of an intention to move or actual moving behaviour. This notwithstanding, the research completed on understanding the relationship between older people's mobility intentions, their actual propensity to move, and the role played by residential satisfaction or dissatisfaction is inconclusive. Some studies have found mobility expectations to be a useful predictor of future mobility (Bradley et al. 2008) and residential satisfaction a significant predictor of actual moves (Erickson et al. 2006). Others have found that although subjective measures of residential satisfaction are strong predictors of thoughts or intentions to move, satisfaction has little direct or indirect effect on people's actual mobility (Landale and Guest 1985). Other research which has not focused specifically on older people finds that neighbourhood satisfaction is an important determinant of residential mobility (Clark and Huang 2003), and that dissatisfaction with housing (Diaz-Serrano 2006) and home environments (Kearns and Parkes 2003) does increase probabilities of housing mobility. 


\section{Conclusion}

From our critical review of the literature, there is a robust body of evidence illustrating the challenges that policy makers need to heed in promoting ageing in place as a 'one stop' solution to later-life aspirations and needs. Furthermore, there are well-recognised conceptual and methodological shortcomings in using residential satisfaction to assess older people's subjective feelings and experiences about where they live, which suggest that it must be subject to more rigorous treatment if it is to be used as a premise for policy makers to promote ageing in place. Our attempt to introduce a conceptual shift from assessing 'satisfaction' to assessing 'dislike' has provided new insight by showing the potential for this concept as an explanatory factor in residential decision-making processes, and these findings can now be built upon by using data sets which provide a wider range of 'push' and 'pull' factors to assess the relative role of dislikes in shaping these processes. We also hope that the findings will bring about a more discerning understanding of whether dislikes can be remedied whilst preserving older people's current residential situation or whether they point to the necessity to relocate - to move on, rather than to age in place.

\section{Acknowledgements}

This research was funded by a research grant awarded to the principal investigator, Dr Sarah Hillcoat-Nallétamby (Centre for Innovative Ageing, Swansea University) by the Welsh Assembly Government's Office of the Chief Social Research Officer (OCSRO) as part of its National Surveys Secondary Analysis Programme. The authors would like to thank OCSRO for their support and technical advice provided during data analysis and drafting processes. Our thanks also extend to The Young Foundation, London for their collaboration and support in the dissemination of the Report's findings.

\section{NOTES}

1 Building for Life is the national standard for well-designed homes and neighbourhoods. See http://webarchive.nationalarchives.gov.uk/2011010716 5544/http://www.buildingforlife.org/about [Accessed 4 August 2012 ].

2 See http://www.nwha.org.uk

\section{References}

Adriaanse, C. C. M. 2007. Measuring residential satisfaction: a Residential Environmental Satisfaction Scale (RESS). Journal of Housing and the Built Environment, 22, 3, 287-304. 
Amérigo, M. and Aragonés, J. I. 1997. A theoretical and methodological approach to the study of residential satisfaction. Journal of Environmental Psychology, 17, 1, $47-57$.

Angelini, V. and Laferrère, A. 2012. Residential mobility of the European elderly. CESifo Economic Studies, 58, 3, 544-569

Appleton, N. 2002. Planning for the Majority. The Needs and Aspirations of Older People in General Housing. Available online at http://www.jrf.org.uk/bookshop/eBooks/ 184263097 o.pdf [Accessed 6 March 2011].

Askham, J., Nelson, H., Tinker, A. and Hancock, R. 1999. To Have and to Hold: The Bond Between Older People and the Homes They Own. York Publishing Services, York, UK.

Audit Commission 1986. Making a Reality of Community Care. Audit Commission, London.

Baldwin, N., Harris, J. and Kelly, D. 1993. Institutionalisation: why blame the institution? Ageing E् Society, 13, 1, 69-81.

Barresi, C. M., Ferraro, K. F. and Hobet, L. L. 1984. Environmental satisfaction, sociability, and well-being among urban elderly. International Journal of Aging and Human Development 18, 4, 277-93.

Barrett, P., Hale, B. and Gauld, R. 201 2. Social inclusion through ageing-in-place with care? Ageing E Society, 32, 3, 361-78.

Boaz, A., Hayden, C. and Bernard, M. 1999. Attitudes and Aspirations of Older People: A Review of the Literature. Department for Work and Pensions Research Report No. 101. Available online at http://research.dwp.gov.uk/asd/asd $5 / 101$ summ.asp [Accessed 3 March 2013].

Bonaiuto, M. 2004. Residential satisfaction and perceived urban quality. In Spielberger, C. (ed.), Encyclopedia of Applied Psychology. Volume 3, Elsevier Academic Press, Oxford, 267-72.

Boyle, G. 2004. Facilitating choice and control for older people in long-term care. Health EO Social Care in the Community 1 2, 3, 21 2-20.

Bradley, D. E., Longino, C. F., Stoller, E. P. and Haas, W. H. 20o8. Actuation of mobility intentions among the young-old: an event-history analysis. The Gerontologist, 48, 2, 190-202.

Brand, C., Hughes, J. and Challis, D. 2012. Towards understanding variations in social care for older people in England. Social Policy $\mathcal{E}$ Administration, 46, 7, $705^{-26 .}$

Burgess, G. 2012. Housing an ageing population: housing options and the value of information and advice to older people in England. Paper presented at the European Network on Housing Research, Lillehammer, Norway, $25^{-27}$ June.

Burholt, V. 2006. Adref: theoretical contexts of attachment to place for mature and older people in rural North Wales. Environment and Planning A, 38, 6, $1095^{-11} 14$.

Canter, D. and Rees, K. 1982. A multivariate model of housing satisfaction. International Review of Applied Psychology, 31, 2, 185-208.

Carp, F. M. and Carp, A. 1982. The ideal residential area. Research on Aging, 4, 4, $411-39$.

Carp, F.M. and Christensen, D. L. 1986. Technical environmental assessment predictors of residential satisfaction. Research on Aging, 8, 2, 269-87.

Castle, N. G. 2001. Relocation of the elderly. Medical Care Research and Review, 58, 3, 291-333.

Chaney, P. 2013. Equality and territorial (in-)justice? Exploring the impact of devolution on social welfare for older people in the UK. Critical Social Policy, 33, 1, $114^{-39}$. 


\section{Sarah Hillcoat-Nallétamby and Jim Ogg}

Chapman, D. W. and Lombard, J. R. 20o6. Determinants of neighborhood satisfaction in fee-based gated and nongated communities. Urban Affairs Review, 41, 6, 769-99.

Clark, W. A. V. and Huang, Y. 2003. The life course and residential mobility in British housing markets. Environment and Planning A, 35, 2, 323-39.

Comas-Herrera, A., Wittenberg, R. and Pickard, L. 2010. The long road to universalism? Recent developments in the financing of long-term care in England. Social Policy E Administration, 44, 4, 375-91.

Croucher, K. 2008. Housing Choices and Aspirations of Older People. Research from the New Horizons Programme. Available online at http://www.communities.gov.uk/ documents/housing/doc/aspirationsresearch [Accessed 3 March 2011].

De Jong, P., Rouwendal, J. and Brouwer, A. 2012. Housing preferences of an ageing population: investigation in the diversity among older adults. Paper presented at the European Network on Housing Research, Lillehammer, Norway, $25^{-27}$ June.

Dekker, K., de Vos, S., Musterd, S. and van Kempen, R. 2011 . Residential satisfaction in housing estates in European cities: a multi-level research approach. Housing Studies, 26, 4, 479-99.

Delhey, J. 2004. Life Satisfaction in an Enlarged Europe. Available online at http:// www.eurofound.europa.eu/pubdocs/2003/108/en/1/efo3108en.pdf [Accessed 29 April 2011 ].

Department for Communities and Local Government 2008. Lifetime Homes, Lifetime Neighbourhoods. A National Strategy for Housing in an Ageing Society. HMSO, London.

Department for Communities and Local Government 2009. Housing in England 2007-08. A Report Principally from the 2007-08 Survey of English Housing. HMSO, London.

Department for Communities and Local Government 2011. A Plain English Guide to the Localism Act. Available online at https://www.gov.uk/government/ uploads/system/uploads/attachment_data/file/5959/1896534.pdf [Accessed 2 December 2011 ].

Department of Health 2001. National Service Framework for Older People. Executive Summary. Available online at http://www.dh.gov.uk/en/publicationandstatistics/ [Accessed 9 January 2012].

Diaz-Serrano, L. 2006. Housing Satisfaction, Homeownership and Housing Mobility: A Panel Data Analysis for Twelve EU Countries. Discussion Paper Series. Available online at http://ssrn.com/abstract=936331 [Accessed 18 July 2012].

Erickson, M. A., Krout, J. A., Ewen, H. and Robison, J. 20o6. Should I stay or should I go? Moving plans of older adults. Journal of Housing for the Elderly, 2o, 3, $5^{-22 .}$

Fausset, C. B., Kelly, A. J., Rogers, W. A. and Fisk, A. D. 2011 . Challenges to aging in place: understanding home maintenance difficulties. Journal of Housing for the Elderly, 25, 2, $125^{-41}$.

Francescato, G. 2002. Residential satisfaction research: the case for and against. In Aragones, G. and Francescato, T. G. (eds), Residential Environments: Choice, Satisfaction and Behavior. Bergin and Garvey, Westport, Connecticut, ${ }_{15}^{-34}$.

Francescato, G., Weidemann, S. and Anderson, J. R. 1987. Residential satisfaction: its uses and limitations in housing research. In Choldin, H., Michelson, W. and Popenoe, D. (eds), Housing and Neighborhoods; Theoretical and Empirical Contributions. Greenwood Press, Westport, Connecticut, 43-57.

Gitlin, L. N. 1998. Testing home modification interventions: issues of theory, measurement, design, and implementation. In Schulz, R., Maddox, G. and Lawton, M. P. (eds), Annual Review of Gerontology and Geriatrics. Interventions Research with Older Adults. Springer, New York, 190-246. 
Golant, S. M. 1984. The effects of residential and activity behaviors on old people's environmental experiences. In Altman, I., Lawton, M. P. and Wohlwill, J. F. (eds), Elderly People and the Environment. Plenum Press, New York, 239-78.

Golant, S. M. 2008. Irrational exuberance for the aging-in-place of vulnerable low-income older homeowners. Journal of Aging and Social Policy, 2o, 4, 379-97.

Greenfield, E. A. 2012. Using ecological frameworks to advance a field of research, practice, and policy on aging-in-place initiatives. The Gerontologist, 52, 1, 1-12.

Harper, L. and Bayer, A.-H. 200o. Fixing to Stay. A National Survey of Housing and Home Modification Issues. AARP Independent Living Program, Washington DC.

Harrison, M. 2004. Defining housing quality and environment: disability, standards and social factors. Housing Studies, 19, 5, 691-708.

Healy, J. D. 2003. Housing conditions, energy efficiency, affordability and satisfaction with housing: a pan-European analysis. Housing Studies, 18, 3, 409-30.

Her Majesty's Government 2011 . Laying the Foundations: A Housing Strategy for England. Available online at http://www.communities.gov.uk/documents/housing/pdf/ 2033676.pdf [Accessed 3 August 2012].

Heywood, F. and Turner, L. 2007. Better Outcomes, Lower Costs: Implications for Health and Social Care Budgets of Investment in Housing Adaptations, Improvements and Equipment: A Review of the Evidence. Office for Disability Issues, Department for Work and Pensions, HMSO, London.

Hillcoat-Nallétamby, S. and Ogg, J. 20o9. To Move or Not to Move? Residential Relocation Behaviour Amongst Older Citizens in Wales. Report Commissioned by The Office of the Chief Social Research Officer (OCSRO) for the National Surveys Secondary Analysis Programme, Welsh Assembly Government, Cardiff.

Homes and Communities Agency, Department of Health, and Communities and Local Government 2009. HAPPI: Housing Our Ageing Population: Panel for Innovation. Available online at http://www.homesandcommunities.co.uk/housingageing-population-panel-innovation [Accessed 14 February 2013].

Hwang, E., Cummings, L., Sixsmith, A. and Sixsmith, J. 2011 . Impacts of home modifications on aging-in-place. Journal of Housing for the Elderly, 25, 3, 246-57.

Kahana, E., Lovegreen, L., Kahana, B. and Kahana, M. 2003. Person, environment and person-environment fit as influences on residential satisfaction of elders. Environment and Behavior, 35, 3, 434-53.

Kearns, A. and Parkes, A. 2003. Living in and leaving poor neighbourhood conditions in England. Housing Studies, 18, 6, 827-51.

Kozma, A. and Stones, M. J. 1983. Predictors of happiness. Journal of Gerontology, 38, 5 , 626-28.

Landale, N.S. and Guest, A. M. 1985. Constraints, satisfaction and residential mobility: Speare's model reconsidered. Demography, 22, 2, 199-222.

Lawton, M. P. 1988. Three functions of the residential environment. Journal of Housing for the Elderly, 5, 1, 35-50.

Lawton, M. P. and Nahemow, L. 1973. Ecology and the aging process. In Eisdorfer, C. and Lawton, M. P. (eds), The Psychology of Adult Development and Aging. American Psychological Association, Washington DC, 619-674.

Lu, M. 1999. Do people move when they say they will? Inconsistencies in individual migration behaviour. Population and Environment, 2o, 5, 467-88.

Lyons, R. A., John, A., Brophy, S., Jones, S. J., Johansen, A., Kemp, A., Lannon, S., Patterson, J., Rolfe, B., Sander, L. V. and Weightman, A. 2006. Modification of the home environment for the reduction of injuries. Cochrane Database of Systematic Reviews, 18, 4, CDoo36oo.

Martin, G. P., Nancarrow, S. A., Parker, H., Phelps, K. and Regen, E. L. 2005. Place, policy and practitioners: on rehabilitation, independence and the therapeutic 


\section{Sarah Hillcoat-Nallétamby and Jim Ogg}

landscape in the changing geography of care provision to older people in the UK. Social Science Ẽ Medicine, 61, 9, 1893-904.

McCormick, J., McDowel, E. and Harris, A. 20o9. Policies for Peace of Mind? Devolution and Older Age in the UK. Available online at http://www.ippr.org/images/media/ files/publication/2011/05/policies_for_peace_of_mind_1729.pdf [Accessed 2 March 2012].

Means, R. 2007. Safe as houses? Ageing in place and vulnerable older people in the UK. Social Policy E् Administration, 4, 1, 65-85.

Means, R. 2011. A brave new world of personalized care? Historical perspectives on social care and older people in England. Social Policy $\mathcal{E}$ Administration, 46, 3, 302-20.

Miller, F. D., Tsemberis, S., Malia, G. P. and Grega, D. 1980. Neighborhood satisfaction among urban dwellers. Journal of Social Issues, 36, 3, 101-1 7 .

Milligan, C. 2009. There's No Place Like Home: Place and Care in an Ageing Society. Ashgate, Farnham, UK.

Mohan, J. and Twigg, L. 2007. Sense of place, quality of life and local socioeconomic context: evidence from the survey of English housing 2002/o3. Urban Studies, 44, $10,2029-45$.

Monk, S. and Burgess, G. 201 2. The role of the planning system in delivering housing choice for older people. Paper presented at the European Network on Housing Research, Lillehammer, Norway, $25^{-2} 7$ June.

Noll, H.-H. 1980. Social Indicators and Social Reporting: The International Experience. Available online at http://www.ccsd.ca/nollı.html [Accessed 20 April 2012].

Noll, H.-H. and Zapf, W. 1994. Social indicators research: societal monitoring and social reporting. In Borg, I. and Mohler, P. (eds), Trends and Perspectives in Empirical Social Research. W. de Gruyter, Berlin, 1-16.

O'Bryant, S. L. and Murray, C. I. 1986. 'Attachment to home' and other factors related to widows' relocation decisions. Journal of Housing for the Elderly, $\mathbf{4}$, $1,53-72$.

Oldman, C. and Quilgars, D. 1999. The last resort? Revisiting ideas about older people's living arrangements. Ageing E Society, 19, 3, 363-84.

Oswald, F. and Rowles, G. D. 20o6. Beyond the relocation trauma in old age: new trends in today's elders' residential decisions. In Wahl, H.-W. and Hoff, A. (eds), New Dynamics in Old Age: Environmental and Societal Perspectives. Baywood Publications, Amityville, New York, 127-52.

Oswald, F., Jopp, D., Rott, C. and Wahl, H.-W. 2010. Is aging in place a resource for or risk to life satisfaction? The Gerontologist, $5^{\mathbf{1}}, 2,23^{8-} 5^{\mathrm{O}}$.

Parkes, A., Kearns, A. and Atkinson, R. 2002. What makes people dissatisfied with their neighbourhoods? Urban Studies, 39, 13, 2413-38.

Peace, S., Hans-Werner, W., Mollenkopf, H. and Oswald, F. 2007. Environment and ageing. In Bond, J., Peace, S., Dittmann-Kohli, F. and Westerhof, G. (eds), Ageing in Society. European Perspectives on Gerontology. Third edition, Sage, London, 209-34.

Peace, S., Holland, C. and Kellaher, L. 2006. Environment and Identity in Later Life. Open University Press, Maidenhead, UK.

Peace, S., Holland, C. and Kellaher, L. 2011. 'Option recognition' in later life: variations in ageing in place. Ageing $\mathcal{E} \sigma$ Society, 31, 5, 734-57.

Peckham, S., Mays, N., Hughes, D., Sanderson, M., Allen, P., Prior, L., Entwistle, V., Thompson, A. and Davies, H. 201 2. Devolution and patient choice: policy rhetoric versus experience in practices. Social Policy $\mathcal{E}^{2}$ Administration, 46, 2, 199-218.

Percival, J. 2002. Domestic spaces: uses and meanings in the daily lives of older people. Ageing E् Society, 22, 6, 729-49. 
Perez, F. R., Fernandex-Mayoralas, G., Rivera, F. E. P. and Abuin, J. M. R. 2001. Ageing in place: predictors of the residential satisfaction of elderly. Social Indicators Research, 54, 2, $173^{-208 .}$

Plath, D. 2008. Independence in old age: the route to social exclusion? British Journal of Social Work, 38, 7, 1353-69.

Porteus, J. 201 1. All Party Parliamentary Group on Housing and Care for Older People. Living Well at Home Inquiry. Available online at http://www.housinglin.org.uk/ _library/Resources/Housing/Support_materials/Other_reports_and_guidance/ living-well-at-home.pdf [Accessed 24 July 2012].

Rabiee, P. 2012. Exploring the relationships between choice and independence: experiences of disabled and older people. British Journal of Social Work, 1-1 7. doi. $10.1093 / \mathrm{bjsw} / \mathrm{bcso} 22$

Rioux, L. and Werner, C. 2011 . Residential satisfaction among aging people living in place. Journal of Environmental Psychology, 31, 2, 158-69.

Rowles, G. D. and Watkins, J. F. 2003. History, habit, heart and hearth. In Schaie, K. W., Wahl, H.-W., Mollenkopf, H. and Oswald, F. (eds), Aging Independently: Living Arrangements and Mobility. Springer, New York, 77-96.

Rubenstein, R. L., Kilbride, J. and Nagy, S. 1992. Elders Living Alone: Frailty and the Perception of Choice. Aldine de Gruyter, Hawthorne, New York.

Sabia, J.J. 20o8. There's no place like home. A hazard model analysis of aging in place among older homeowners in the PSID. Research on Aging, 3o, 1, $3-35$.

Sanchez, A. C. and Andrews, D. 2011 . To Move or Not to Move: What Drives Residential Mobility Rates in the OECD? Organisation for Economic Co-operation and Development, Paris.

Scheidt, R. J. 1993. Place and personality in adult developments. In Kastenbaum, R. (ed.), Encyclopedia of Adult Development. Oryx Press, Phoenix, Arizona, 370-7.

Seppänen, M. 2012. Ageing in place and attachment to urban neighbourhoods. Paper presented at the British Society of Gerontology's Annual Conference, 1 1-13 July, Keele University, UK.

Sima, J., Liddlea, J., Bernarda, M., Scharfb, T. and Bartlam, B. 201 2. Home from home? A mixed-methods study of relocation within a purpose-built retirement community. Journal of Housing for the Elderly, 26, 4, 372-94.

Sixsmith, A. and Sixsmith, J. 2008. Ageing in place in the United Kingdom. Ageing International, 32, 3, 219-35.

Stimson, R.J. and McCrea, R. 2004. A push-pull framework for modelling the relocation of retirees to a retirement village: the Australian experience. Environment and Planning $A, \mathbf{3}^{6}, 8,145^{1-70}$.

Wasserman, I. M. 1982. Size of place in relation to community attachment and satisfaction with community services. Social Indicators Research, 1 1, 4, 421-36.

Weeks, L. E., Keefe, J. and Macdonald, D.J. 2012. Factors predicting relocation among older adults. Journal of Housing for the Elderly, 26, 4, 355-71.

Welsh Assembly Government 2004. Policy Review. Housing for Older People. Final Report. The Social Justice and Regeneration Committee, Cardiff, UK.

Welsh Assembly Government 2008a. Living in Wales 2007-Housing Tenure. Welsh Assembly Government, Cardiff, UK.

Welsh Assembly Government 2008b. Citizens First. Wales Improving Public Service Delivery. Findings from the 2006 Living in Wales Survey into Citizens' Views of Public Services. Part 2-Housing Advice Services. Welsh Assembly Government, Cardiff, UK.

Zapf, W. 1984. Individuelle Wohlfahrt: Lebensbedingungen und wahrgenommene Lebensqualität [Individual welfare: Living conditions and perceived quality 
1796 Sarah Hillcoat-Nallétamby and Jim Ogg

of life]. In Zapf, W. G. W. (ed.), Lebensqualität in der Bundesrepublik. Campus Verlag, Frankfurt, Germany, 13-26.

Zapf, W. 2000. Social reporting in the 1970 and in the 1990 . Social Indicators Research, 51, 1, 1-15.

Accepted 8 July 2013; first published online 9 August 2013

Address for correspondence:

Sarah Hillcoat-Nalletamby, Centre for Innovative Ageing,

College of Human and Health Sciences,

Swansea University, Singleton Park,

Swansea, SA2 8PP, Wales.

E-mail: S.Hillcoat-Nalletamby@swansea.ac.uk 